\title{
Correction: Autophagy provides a conceptual therapeutic framework for bone metastasis from prostate cancer
}

YouZhi Wang, Ning Wu and Ning Jiang (D

(c) The Author(s) 2021

Cell Death and Disease (2021)12:1021; https://doi.org/10.1038/s41419-021-04341-z

Correction to: Cell Death and Disease https://doi.org/10.1038/ s41419-021-04181-x, published online 05 October 2021

The original version of this article unfortunately contained a mistake in the Funding section. The correction in funding is: This work was supported by National Natural Science Foundation of China [grant numbers 81872079 and 81572538], the Natural Science Foundation of Tianjin City [grant numbers 11JCZDJC19700, 16JCZDJC34400, 20140117, and 2010KZ95] and Tianjin Municipal Bureau of Public Health [grant numbers ZC20131]. The original article has been corrected.

\begin{abstract}
Open Access This article is licensed under a Creative Commons Attribution 4.0 International License, which permits use, sharing, adaptation, distribution and reproduction in any medium or format, as long as you give appropriate credit to the original author(s) and the source, provide a link to the Creative Commons license, and indicate if changes were made. The images or other third party material in this article are included in the article's Creative Commons license, unless indicated otherwise in a credit line to the material. If material is not included in the article's Creative Commons license and your intended use is not permitted by statutory regulation or exceeds the permitted use, you will need to obtain permission directly from the copyright holder. To view a copy of this license, visit http://creativecommons. org/licenses/by/4.0/.
\end{abstract}

(c) The Author(s) 2021 